\title{
Chemical Quality of Longissimus Muscles of Kacang Goat After Supplemented With A Combination of Palm Kernel Meal and Powdered Katuk Leaf
}

\author{
Razali Razali $^{1^{*}}$, Teuku R. Ferasyi ${ }^{1}$, Azhari Azhari ${ }^{1}$, Rastina Rastina ${ }^{1}$, Ismail Ismail ${ }^{1}$, Anwar Anwar ${ }^{2}$, Rijanto \\ Hutasoit $^{2}$, and Andi Tarigan ${ }^{2}$ \\ ${ }^{1}$ Faculty of Veterinary Medicine, Universitas Syiah Kuala, Darussalam, Banda Aceh \\ ${ }^{2}$ Centre for Meat Goat Research, Sei Putih, North Sumatera
}

\begin{abstract}
The purpose of this study was to analyze the effect of supplementation of palm kernel meal (BIS), Katuk leaf powder (KAT), and their combination on the chemical quality of Longissimus dorsi muscle in Kacang goats. Twenty male Kacang goats aged \pm 1.5 years old with the average live body weight of $15.42 \pm 1.28 \mathrm{~kg}$ were used in this research. A complete randomized design was used in this research; with 4 treatments and 5 replications. All goats were acclimatized for 2 weeks. Group P0 as control was given distilled water. Group P1 was given BIS at a dose of $100 \mathrm{gr} /$ day/head. Group P2 was administered with BIS 100 $\mathrm{gr} /$ day/head and Katuk leaf powder $15 \mathrm{gr} /$ day/head, and group P3 was given KAT $15 \mathrm{gr} / \mathrm{day} / \mathrm{head}$. The treatments were given twice per day for 35 consecutive days and goats were fed with leaves and grasses, and had access to water ad libitum. At the day 25 and 50 after treatment, goats were slaughtered according to standard commercial halal procedures. $L$. dorsi muscles were taken and subjected to measurement of moisture content, crude protein, fat, ash content, and cholesterol. The results showed that KAT statistically $(\mathrm{P} \leq 0,05)$ reduces cholesterol and fat contents of $L$. dorsi muscles. In conclusion, the administration of KAT may reduce cholesterol and fat.
\end{abstract}

Keywords: palm kernel meal, Katuk leaf powder, Longissimus dorsi, Kacang goats.

\section{Introduction}

Physical and chemical quality are important aspects of meat quality assessment. Meat quality plays an important role in consumers and meat processing. Normally meat is not only assessed from muscle, fat, and bone aspects, but also other constituents such as water, fat, crude fiber, ash, and cholesterol contents [1]. Several researchers have been conducted to assess the physical quality and chemical composition of goat or sheep fed by certain grass or herbal feeds $[2,3,4,5]$.

The use of herbs or herbal products to improve production or quality of meat chemical components has been practiced by several researchers. Herbal products from certain plants are believed to increase production. Several consumers and farmers are aware and implementing concepts and patterns under a clean, green, and ethical basis [6]. This practice is implemented to provide comfort for costumers especially in the field of food hygiene.

The use of the herbal product is more preferred by consumers not only from the animal welfare point of view but also human health. It has been known that goat meat has a low level of intramuscular fat and high in water content [2,7] if compared with similar culling age and body weight.
Although there are a lot of documentations on goat meat chemical composition $[8,4]$, there is still limited information about the chemical composition of goat meat after being fed field grass with a combination of palm kernel meal. Thus, further information about the parameter in Kacang goat after being giving BIS and Katuk leaf power (KAT) is required.

\section{Materials and Methods}

\subsection{Location}

The research was conducted in Sei Putih District, North Sumatera Province. It was located in 3025'04.4"N 98 o53'04.0"E with 43,7 m elevation above sea level. The area has a warm climate with the temperature hovering between $290 \mathrm{C}$ to $300 \mathrm{C}$ and rainfall from moderate to heavy.

\subsection{Animal Treatment}

Twenty local Kacang goats obtained from the market and breeding around the research area Sei Putih District. Goats were then separated according to body weight from $14 \mathrm{~kg}$ to $19 \mathrm{~kg}$ (average live body weight $15,42 \pm 1.28 \mathrm{~kg}$ )

*Corresponding author: razali@unsyiah.ac.id 
and according to age from 1,5 to 2 years old. Goat age was calculated through the eruption pattern of incision teeth, where goats selected as samples must have a pair of first permanent incision teeth.

All animals were acclimatized for 14 days with field grass feed. Every day the goats were given fed natural grass and water ad libitum. After the acclimatization period passed, with complete random sampling design (CRD) the goats were randomly placed in individual cages and divided into 4 groups consisting of 5 animals each. The first group is the control group (P0) given only distilled water. The first, second, and third groups were treatment groups. P1 group was given BIS 100g/day per animal, the P2 group was given BIS and KAT 100g/day and $15 \mathrm{~g} /$ day per animal each. P3 group was only given KAT $15 \mathrm{~g} /$ day per animal. All treatments were given orally two times a day; in the morning at 07:30 and in the afternoon at 16:30.

\subsection{Culling Procedure}

On day 25 and 50 of treatment, two to three animals from every treatment were culled with halal practice. After 24 hours of carcass storage, the muscle portion of Longissimus muscle was sampled as much as $100 \mathrm{~g}$ for further chemical analysis examination. Chemical composition analysis was conducted based on proximate analysis to determine water, fat, crude protein, ash, and cholesterol content [9] utilizing facilities in the Production and Nutrition Science Department, Bogor Agricultural Institute.
All goats were slaughtered with halal practice on day 25 after treatment for the first wave and 50 days after treatment for the second wave. Before slaughtering, goats have fasted for 10 hours. After slaughtered, carcasses were placed in 200C storage with $70 \%$ humidity. Carcasses were separated into symmetrical left and right portions. Samples were taken from the right half portion of carcass by L. dorsi muscle [10]. Samples for analysis were weighted $100 \mathrm{~g}$. Samples were placed in plastic containers, labeled, and taken to the laboratory. The parameter measured were water, fat, crude protein, ash, and cholesterol content. The method used for chemical analysis is the Gravimetric method for water content, Kjeldahl method for protein analysis, Soxhlet method for fat content analysis, and Lieberman-Burchards for cholesterol analysis [9]. Data obtained was analyzed by Anova, variance analysis to compare calculated $\mathrm{F}$ with $\mathrm{F}$ table with 5\% significance. If a significant difference was found, the result will be followed by Duncan's multiple distance test [12].

\section{Results and Discussion}

Research results showed that water, ash, and crude protein content of Kacang goat from all treatment groups did not significantly differ with each other $(\mathrm{P}>0.05)$, but fat and cholesterol content showed significant differences. The full result is presented in the following table.

Table 1. The average value of chemical composition (\% sample weight) of Kacang goat $L$. dorsi muscle ( $\mathrm{n}=20)$

\begin{tabular}{lccccccr}
\hline \multirow{2}{*}{ Variable } & \multicolumn{9}{c}{$25^{\text {th }}$ day } & \multicolumn{3}{c}{$50^{\text {th }}$ day } \\
\cline { 2 - 8 } & Control & BIS & BIS+KAT & KAT & BIS & BIS+KAT & \multicolumn{1}{c}{ KAT } \\
\hline Moisture (\%) & $77,89 \pm 0.21$ & $78,66 \pm 0.37$ & $79,84 \pm 0.83$ & $79,18 \pm 0.64$ & $78,20 \pm 0.37$ & $79,84 \pm 0.83$ & $79,38 \pm 0.24^{n s}$ \\
Fat (\%) & $0,53 \pm 0.20^{b}$ & $0,64 \pm 0.10$ & $0,51 \pm 0.16$ & $0,18 \pm 0.62^{a}$ & $0,44 \pm 0.10$ & $0,51 \pm 0.46$ & $0,12 \pm 0.62^{a}$ \\
Crude Protein (\%) & $16,67 \pm 0.93$ & $16,61 \pm 0.92$ & $18,63 \pm 1.97$ & $18,35 \pm 0.68$ & $17,61 \pm 0.92$ & $18,33 \pm 1.97$ & $18,05 \pm 0.68^{n s}$ \\
Ash (\%) & $1,22 \pm 0.02$ & $1,12 \pm 0.02$ & $1,02 \pm 0.0$ & $1,05 \pm 0.05$ & $1,12 \pm 0.02$ & $1,02 \pm 0.06$ & $1,05 \pm 0.05^{n s}$ \\
Cholesterol & $76,1 \pm 0,8^{b}$ & $75,07 \pm 0,7$ & $68,3 \pm 0,5$ & $59,9 \pm 0,7^{a}$ & $79,3 \pm 0,5$ & $66,1 \pm 0,8$ & $55,07 \pm 0,7^{a}$ \\
(mg/100g) & & &
\end{tabular}

${ }^{a b}$ The means with different letters in the same row indicated significantly different ( $\left.p \leq 0.05\right)$, ns: not significant

Meat water content obtained in this research after day 25 of treatment did not differ significantly $(\mathrm{P}>0.05)$ with the result obtained after 50 days of treatment. Factors influencing water content are livestock species, age, gender, feed, location and part of muscle [11]. According to Anggorodi [13], water and fat content are influenced by age and feed composition. Fat content measurement results in this research were significantly lower $(\mathrm{P}<0.05)$ compared to control. Fat content in L. dorsi muscle on day 25 and 50 after KAT treatment were $0,18 \pm 0.62 \%$ and $0,12 \pm 0.62 \%$.

Based on research done by Aqsa et al. [14] it is reported that Kacang goat water content is $77,2 \%$, higher than the result obtained in this research. It could be assumed that meat water content in this research is still within normal for it hovers between $65-80 \%$ [10].
The fat content obtained in this research was significantly different $(\mathrm{P} \leq 0.05)$ compared to the result obtained from control. Average fat content in the control group, BIS group, BIS-KAT group, and KAT group after 25 and 50 days of treatments were $0.53 \%, 0.44 \%, 0.51 \%$, and $0.18 \%$. The same result was also obtained in day 50 of treatment. Fat content obtained in this research also significantly different, similar to cholesterol content. Based on the result obtained in this research, it can be said that Kacang goat cannot store excess energy consumption and feed protein will be changed into fat or marbling. Fat content in Kacang goat used in this research is slightly higher compared to the research done by Soeparno et al. [15] and Aqsa et al. [14] which were $1.79 \%$ and $2.09 \%$ respectively, and lower compared to the result done by Agnihotri et al. [16] where Barbari goat showed to have fat content of $4.8 \%$. 
Meat cholesterol level obtained in this research is significantly different $(\mathrm{P} \leq(0.05)$ if the control group is to be compared with the group given BIS or BIS-KAT combination. The average cholesterol level in this research after KAT administration was $59.9 \mathrm{mg} / 100 \mathrm{~g}$ after 25 days and $55.07 \mathrm{mg} / 100 \mathrm{~g}$ after 50 days. This is in accordance with Pratiwi et al. [17] who stated that meat cholesterol level is closely related to Fat content and is influenced by fatty acid composition. Meat cholesterol level obtained in this research is lower compared to the results obtained by Aqsa et. al. [14] which is 76.50 $\mathrm{mg} / 100 \mathrm{~g}$ meat.

\section{Conclusion}

It can be concluded that Katuk leaf powder can lower fat and cholesterol content but cannot influence water, crude protein, and ash contents.

\section{Acknowledgments}

The financial support from PPUPT funded by DRPM Ristek Dikti 2018 and the Centre for Meat Goat Research, Sei Putih, North Sumatera is highly acknowledged. Gratitude is given to the Faculty of Veterinary Medicine of Syiah Kuala University, Darussalam Banda Aceh.

\section{References}

1. Moran JB, Wood JT: Comparative performance of $\mathbf{5}$ genotypes of Indonesian large ruminants. Growth and development of carcass tissues. Aust. J. Agric. Res. 1986; 37:435-447.

2. Babiker SA, El Khider IA, Shafie SA: Chemical composition and quality attributes of goat meat and lamb. Meat Sci.1990; 28:273-277.

3. Sen AR, Santra A, Karim SA: Carcass yield, composition and meat quality attributes of sheep and goat under semiarid conditions. Meat Sci. 2004; 66:757-763.

4. Santos VA, Silva CSR, Azevedo JMT: Carcass composition and meat quality of equally mature kids and lambs. J. Anim. Sci. 2008; 86:1943-1950.

5. Razali, Mahdi A, Teuku R. Ferasyi, et al. :: Physical Quality of Longissimus Muscles of Kacang Goat After Supplemented With a Combination of Palm Kernel Meal and Powdered Katuk Leaf. The 4th International Conference on Biological Sciences and Biotechnology. 2019.
6. Ferasyi TR, Muslim A, Fitra AP,et al. : The First International Symposium on Food and Agrobiodiversity (ISFA2014). Procedia Food Science. 2015; 3:389-395.

7. Mahgoub, O, Lodge GA: A comparative study on growth, body composition and carcass tissue. distribution in Omani sheep and goats. J. Agric. Sci. 1998; 131:329-339.

8. Lee JH, Kannan G, Eega KR, et al. : Nutritional and quality characteristics of meat from goats and lambs finished under identical dietary regime. Small Rumin. Res. 2008; 74:255-259.

9. AOAC: Official methods of analysis (18th ed.). Association of Official Analytical Chemists. Arlington, VA, USA. 2007

10. Soeparno: Ilmu dan Teknologi Daging. Gadjah Mada University Press, Yogyakarta, 2009.

11. Romans JR, Costello WJ, Carlson CW, et al. : The Meat We Eat. Interstate Publisher, Inc. Danville, Illionis. 1994.

12. Gomez, KA, Gomez AA: Prosedur Statistik untuk Penelitian Pertanian. Edisi Kedua (Diterjemahkan oleh E. Sjamsuddin dan J. S. Baharsjah). Penerbit Universitas Indonesia. Jakarta, 1995.

13. Anggorodi R: Ilmu Makanan Ternak Umum. PT Gramedia, Jakarta, 1994.

14. Aqsha, Purbowati GEE, Al-Baari AN: Komposisi kimia daging kambing kacang, Peranakan Ettawa, dan Kecobong pada umur satu tahun. Prosiding Workshop Nasional Diversifikasi Pangan Daging Ruminansia Kecil, Jakarta. 2011;104-109.

15. Soeparno, Setiyono, Djojowidagdo S: Peningkatan produksi dan kualitas daging kambing. Laporan Peneletian, Universitas Gadjah MadaYogyakarta, 1993.

16. Agnihotri MK, Rajkumar V, Dutta TK: Effect of feeding complete rations with variable protein and energy levels prepared using by products of pulses and oilseeds on carcass characteristics, meat, and meat ball quality of goats.Asian-Aust.J.Anim.Sci. 2006; 19(10):1437-1449.

17. Pratiwi NMW, Murray PJ, Taylor DG: Feral goats in Australia: A study on the quality and nutritive vaue of their meat. Meat Sci.. 2007; 75(2007):168-177. 